Systematic Review

\title{
Neuropathic Pain in Acute and Subacute Neuropathies: A Systematic Review
}

Artemios K. Artemiadis, MD, PhDc ${ }^{1}$ and Panagiotis Zis, MD, $\mathrm{PhD}^{2}$

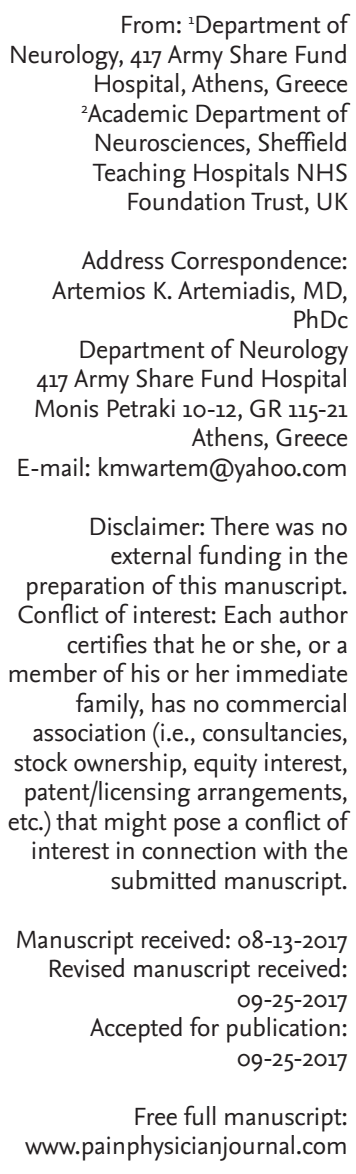

From: ${ }^{2}$ Department of Neurology, 417 Army Share Fund

Hospital, Athens, Greece

${ }^{2}$ Academic Department of

Neurosciences, Sheffield

Teaching Hospitals NHS

Foundation Trust, UK

Address Correspondence: Artemios K. Artemiadis, MD,

$\mathrm{PhDc}$

Department of Neurology 417 Army Share Fund Hospital Monis Petraki 10-12, GR 115-21 Athens, Greece

E-mail:kmwartem@yahoo.com

Disclaimer: There was no external funding in the preparation of this manuscript. Conflict of interest: Each author certifies that he or she, or a member of his or her immediate family, has no commercial association (i.e., consultancies, stock ownership, equity interest, patent/licensing arrangements, etc.) that might pose a conflict of interest in connection with the submitted manuscript.

Manuscript received: 08-13-2017 Revised manuscript received: 09-25-2017 Accepted for publication: 09-25-2017

Free full manuscript: www.painphysicianjournal.com

Background: Neuropathic pain (NP) is a common symptom caused by lesions or diseases of the somatosensory nervous system. Acute/subacute peripheral neuropathies (APN) are rare, however can be particularly painful.

Objectives: The aim of this systematic review was to estimate the incidence of NP in APN and overview the various etiologies of such neuropathies.

Study Design: Systematic review.

Setting: Medline search.

Methods: We hand-searched Medline for observational studies published between 1995 and 2017.

Results: Our search strategy identified 1,400 papers. Of these, 70 met our inclusion criteria and were included in this review. Out of a total of 2,341 patients, 1,139 patients were diagnosed with NP (pooled incidence of NP 48.7\%). In Guillain-Barré syndrome (GBS), the commonest cause of APN, the pooled estimate of NP was $34.8 \%$. Other causes of painful APN include immunemediated, vasculitic, metabolic, nutritional, toxic, paraneoplastic, and infectious.

Limitations: An important limitation was that GBS accounted for the majority of patients with APN, as such the calculated incidence reflected mainly this disease entity. Another important limitation was that very few studies targeted primarily NP. Thus, it is highly likely that observational studies reporting NP were missed. Finally there could always be a publication bias due to underreporting and gray literature.

Conclusions: NP is a cardinal manifestation of APN. The use of validated diagnostic tools and accepted diagnostic criteria of NP is recommended for both clinical and research purposes.

Key words: Neuropathic, pain, acute, subacute, neuropathy, polyneuropathy, frequency, incidence

Pain Physician 2018; 21:111-120

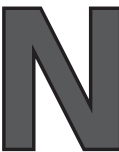
europathic pain (NP) is estimated to affect $6-8 \%$ of the general population in Europe causing poor general health and low quality of life (1). The International Association for the Study of Pain defines NP as "pain initiated or caused by a primary lesion or dysfunction in the nervous system" (2). Treede et al (3) in 2008 proposed a different definition of NP as "pain arising as a direct consequence of a lesion or disease affecting the somatosensory system." In general, NP can be caused by lesions of the central or the peripheral nervous system, or both, and may be acute, subacute, or chronic $(4,5)$.

The diagnosis of NP remains principally clinical and it is based on the detection of both dysesthesias (i.e., burning, cold, pricking, shooting, electric shocklike, tingling, itching, pins and needles, stabbing, lancinating, and other painful sensations) and negative symptoms (i.e., numbness, hypoesthesia, anesthesia, 
etc.) (5). Hyperalgesia (i.e., increased pain in response to a painful stimulus, e.g., by a pin, painful heat, or cold) and allodynia (i.e., pain in response to a nonpainful stimulus, e.g., thermal, vibration, mechanical static pressure, or mechanical dynamic moving light touch) are pathognomonic symptoms of NP, reflecting excessive activity of the sensory system due to a lower threshold or excessive activity (5).

Despite the importance of the clinical diagnosis of NP, the need for consistency among health professionals has led to the adoption of several "objective" screening tools of NP. Examples are the McGill pain questionnaire (or its short form) $(6,7)$, the neuropathic pain scale (8), the neuropathic pain symptom inventory (9), and others (e.g., Pain Detect, ID-Pain, DN4 -douleur neuropathique- and LANSS pain scale - Leeds assessment of neuropathic symptoms and signs) $(5,10)$.

Causes of painful peripheral neuropathies are numerous, however, occasionally patients might suffer from idiopathic (of unknown etiology) painful neuropathies $(11,12)$. This article focuses solely on acute and subacute peripheral neuropathies. The primary aim of this systematic review was to explore the incidence of pain in such neuropathies. We also aimed to overview the causes of acute and subacute painful peripheral neuropathies.

\section{Methods}

We hand-searched MEDLINE for articles published since January 1, 1995 using English language restrictions (last search in June 2017). The search strategy included the following keywords: "pain OR painful OR neuralgia," "acute OR subacute," and "neuropathy OR polyneuropathy OR polyradiculopathy OR neuronopathy OR neuritis OR mononeuritis OR ganglionopathy OR guillain-barré OR Miller-Fisher." Only observational studies were included (i.e., cohorts, case-control, crosssectional, case series, and case reports) after careful screening of titles, abstracts, or full-texts. Articles referring to children, mononeuropathies, monoradiculopathies, traumatic, or ischemic neuropathies were excluded (e.g., carpal tunnel syndrome and other entrapment neuropathies, post-herpetic neuralgia, ischemic monomelic neuropathy after hemodialysis, etc). Articles with vague definitions of pain, not specifying if it is NP or not, were also excluded to avoid bias. The literature search and the study selection were independently conducted by both authors. We also perused the reference lists of the papers in order to find papers not found through the above mentioned search strategy.
Data extraction included the following characteristics: disease type, sample size, demographics (age and gender), incidence of NP, method of NP diagnosis, and definitions of "acute" and "subacute". The incidence of NP was derived by studies with more than 10 patients.

\section{Results}

\section{Search Results}

The search strategy resulted in 1,400 articles. After eligibility assessment, 70 articles met our inclusion criteria. Of these, 29 were identified as observational studies of more than 10 patients reporting on the incidence of NP. The other 41 were case reports or small case series studies.

\section{Incidence of NP in Acute/Subacute Neuropathies}

A total of 2,341 patients (1,108 women and 1,233 men, mainly middle-aged) with acute/subacute neuropathies were described in the studies (13-41). The majority of the patients had Guillain-Barré syndrome (GBS) $(1,529$ of $2,341,65.3 \%)$. In total, 1,139 patients were diagnosed with NP (pooled incidence 48.7\%). The disease-specific NP incidence was: GBS or MillerFisher syndrome (MFS) 34.8\%, (range: 9.6\%-85.5\%), treatment-induced peripheral neuropathy of diabetes (TIND) 100\%, diabetic cervical/lumbar radiculo-plexopathy $86.4 \%$ (range: $81.2-100 \%$ ), acute chemotherapyinduced peripheral neuropathy (ACIPN) $85 \%$ (range: 56.3-88.5\%), Sjögren 12\%, Churg-Strauss syndrome (CSS) $94.9 \%$ (range: $81.8-100 \%$ ), nonsystemic vasculitic neuropathy (NSVN) $60 \%$, infections $41.2 \%$, toxic $100 \%$, acute autonomic and sensory neuropathy (AASN) $95.2 \%$, post-surgical neuropathy (PSN) $85.7 \%$, acute nutritional neuropathy (ANN) $100 \%$, and acute/subacute paraneoplastic neuropathy $75 \%$. Table 1 summarizes the characteristics of the studies used for calculating the incidence of NP in acute/subacute neuropathies.

\section{Causes of Acute/Subacute Painful Neuropathies}

Common causes of acute/subacute neuropathies are reported below (13-41). Rare causes of acute/subacute neuropathies are summarized in Table 2 (42-82).

\section{Immune-mediated Acute/Subacute Neuropathies}

GBS is an acute immune-mediated polyradiculoneuropathy causing acute weakness and disability in affected patients. The types of pain in GBS include 
Neuropathic Pain in Acute and Subacute Neuropathies

Table 1. Observational studies of patients with acute neuropathies and the incidence of neuropathic pain.

\begin{tabular}{|c|c|c|c|c|c|}
\hline Reference & $\begin{array}{c}\text { Disease } \\
\text { (Number of } \\
\text { patients) }\end{array}$ & $\begin{array}{c}\text { Demographics } \\
\text { (age in years old, Women/ } \\
\text { Men ratio) }\end{array}$ & $\begin{array}{c}\text { Definition of } \\
\text { acute/subacute }\end{array}$ & Sensory assessments & $\begin{array}{c}\text { Incidence of } \\
\text { Neuropathic } \\
\text { Pain }\end{array}$ \\
\hline 13) & GBS (541) & $\begin{array}{l}\text { Mean } 41.6 \pm 15.3 \\
210 / 331\end{array}$ & Days (vague) & Clinical & $52 / 541$ \\
\hline 14 & $\begin{array}{l}\text { Pure motor GBS } \\
\text { Europe: } 225 \\
\text { Curacao: } 83\end{array}$ & $\begin{array}{c}\text { Europe: } \\
\text { Median } 55(20-74) \\
95 / 130 \\
\text { Curacao: Median } 44 \text { (6-71) } \\
33 / 50\end{array}$ & $\leq 1$ month & Clinical, EPT & $\begin{array}{c}123 / 225 \\
39 / 83\end{array}$ \\
\hline 15 & GBS (223) & $\begin{array}{c}\text { Median } 50 \\
123 / 130 \\
\end{array}$ & $\leq 1$ month & $\begin{array}{c}\text { Nonvalidated self-reported } \\
\text { questionnaires }\end{array}$ & $123 / 223$ \\
\hline 16 & GBS (156) & $\begin{array}{c}\text { Median } 50(35-63) \\
61 / 95\end{array}$ & $\leq 3$ weeks after onset & $\begin{array}{c}\text { Clinical } \\
\text { MPQ, NRS, EPT }\end{array}$ & $43 / 152$ \\
\hline 17 & GBS (110) & $\begin{array}{c}\text { Median 49.6 (IQR 16.7) } \\
68 / 42\end{array}$ & $24 \mathrm{hr}$ after admission & $\begin{array}{l}\text { Clinical, nonvalidated } \\
\text { questionnaire, EPT }\end{array}$ & $30 / 110$ \\
\hline 18 & GBS (55) & $\begin{array}{c}\text { Mean } 50.6 \\
21 / 34\end{array}$ & On admission & Clinical, NRS, MPQ & $47 / 55$ \\
\hline 19 & GBS (42) & $\begin{array}{c}\text { Mean } 52 \pm 18(20-80) \\
18 / 24\end{array}$ & $\leq 2$ weeks & Clinical, NRS & $30 / 42$ \\
\hline 20 & GBS/MFS (32) & $\begin{array}{c}\text { GBS: } 52 \pm 15 \\
\text { MFS: } 54 \pm 17 \\
13 / 19\end{array}$ & $\leq 3$ weeks & $\begin{array}{c}\text { Clinical, Unknown } \\
\text { questionnaire, NRS, SB }\end{array}$ & $14 / 32$ \\
\hline 21 & GBS (30) & $\begin{array}{c}\text { Mean 59.3 } \pm 17.2(21-81) \\
14 / 16\end{array}$ & $\begin{array}{l}\text { Within days after } \\
\text { admission }\end{array}$ & $\begin{array}{c}\text { Clinical, BPI, DN4, MPQ, NPSI, } \\
\text { QST, EPT }\end{array}$ & $13 / 30$ \\
\hline 22 & GBS (24) & $\begin{array}{c}\text { Mean } 51(16-84) \\
14 / 10\end{array}$ & $\begin{array}{c}\text { During } \\
\text { hospitilization }\end{array}$ & $\begin{array}{c}\text { Clinical, Nonvalidated pain } \\
\text { questionnaire, EPT }\end{array}$ & $14 / 24$ \\
\hline 23 & Mild GBS ${ }^{1}(12)$ & $\begin{array}{c}\text { Median } 52(19-64) \\
5 / 7\end{array}$ & At presentation & Clinical, EPT & $7 / 12$ \\
\hline 24 & MFS (27) & $\begin{array}{c}\text { Median } 38(10-75) \\
14 / 13\end{array}$ & At Presentation & Nonvalidated questionnaire & $6 / 27$ \\
\hline 25 & TIND (104) & $\begin{array}{c}\text { DM1: Mean } 25 \pm 6.7 \\
\text { DM2: Mean } 50.9 \pm 6.8 \\
73 / 31\end{array}$ & $\leq 8$ weeks & Clinical, NIS, EPT, NRS & $104 / 104$ \\
\hline 26 & $\begin{array}{l}\text { TIND (summary } \\
\text { of } 34 \text { cases) }\end{array}$ & $\begin{array}{c}\text { Mean } 47.7 \\
13 / 14\end{array}$ & $\mathrm{n} / \mathrm{a}$ & Clinical, EPT & $34 / 34$ \\
\hline 27 & TIND (16) & $\begin{array}{c}\text { Mean } 34.6(19-58) \\
9 / 7\end{array}$ & $\mathrm{n} / \mathrm{a}$ & Clinical, NIS, NRS, SB & $16 / 16$ \\
\hline 28 & $\begin{array}{l}\text { DCRPN (85) and } \\
\text { DLRPN (33) }\end{array}$ & $\begin{array}{c}\text { Median } 62(51-66) \text { and } \\
\text { Median } 65(60-71) \\
29 / 56 \text { and } \\
13 / 20\end{array}$ & $\begin{array}{l}\text { Acute: } \leq 24 \mathrm{hr} \\
\text { Subacute: } \\
\text { 1day-1month }\end{array}$ & $\begin{array}{l}\text { Clinical, EPT, } \\
\text { QST,NB }\end{array}$ & $\begin{array}{l}69 / 85 \text { and } \\
33 / 33\end{array}$ \\
\hline 29 & ACIPN (86) & $\begin{array}{c}\text { Median } 56(26-74) \\
30 / 56\end{array}$ & $\begin{array}{l}\text { Within } 24 \mathrm{hrs} \text { after } \\
\text { oxaliplatin }\end{array}$ & Clinical, nonvalidated interview & $75 / 86$ \\
\hline 30 & ACIPN (81) & $\begin{array}{c}\text { Mean } 60.5(33-89) \\
60 / 21\end{array}$ & $\begin{array}{c}\leq 7 \text { days after } \\
\text { paclitaxel infusion }\end{array}$ & Nonvalidated Questionnaire & $69 / 78$ \\
\hline 31 & ACIPN (16) & $\begin{array}{c}\text { Mean } 64.6 \pm 12.4^{*} \\
11 / 5\end{array}$ & $\begin{array}{l}\text { After oxaliplatin } \\
\text { infusion }\end{array}$ & MPQ, QST & $9 / 16$ \\
\hline 32 & Sjögren (92) & $\begin{array}{c}\text { Mean } 58.1 \pm 15.9^{*} \\
76 / 16\end{array}$ & $\begin{array}{l}\text { Symptoms present } \\
\text { for days or weeks }\end{array}$ & Clinical, EPT, NB & $11 / 92$ \\
\hline 33 & NSVN (60) & $\begin{array}{c}\text { Median } 64(24-80) \\
21 / 39\end{array}$ & Admission & Clinical, NSS, NDS, EPT, NB & $36 / 60$ \\
\hline
\end{tabular}


Pain Physician: March/April 2018; 21:111-120

Table 1 (cont.). Observational studies of patients with acute neuropathies and the incidence of neuropathic pain.

\begin{tabular}{|c|c|c|c|c|c|}
\hline Reference & $\begin{array}{c}\text { Disease } \\
\text { (Number of } \\
\text { patients) }\end{array}$ & $\begin{array}{c}\text { Demographics } \\
\text { (age in years old, Women/ } \\
\text { Men ratio) }\end{array}$ & $\begin{array}{c}\text { Definition of } \\
\text { acute/subacute }\end{array}$ & Sensory assessments & $\begin{array}{c}\text { Incidence of } \\
\text { Neuropathic } \\
\text { Pain }\end{array}$ \\
\hline 34 & CSS (28) & $\begin{array}{c}\text { Mean } 52.4(22-78) \\
22 / 6\end{array}$ & $\leq 1$ week & Clinical, EPT, NB & $28 / 28$ \\
\hline 35 & CSS (11) & $\begin{array}{c}\text { Mean } 53(45-63) \\
6 / 5\end{array}$ & $\begin{array}{l}\text { Acute: } \leq 1 \text { month, } \\
\text { Subacute: } 1-3 \\
\text { months }\end{array}$ & Clinical, EPT & $9 / 11$ \\
\hline 36 & $\begin{array}{c}\text { Tick borne } \\
\text { encephalitis and } \\
\text { Lyme borreliosis } \\
\text { (51) }\end{array}$ & $\mathrm{n} / \mathrm{a}$ & At presentation & Clinical & $21 / 51$ \\
\hline 37 & $\operatorname{Toxic}^{\S}(24)$ & $\begin{array}{c}\text { Median } 33(20-54) \\
14 / 10\end{array}$ & $\mathrm{n} / \mathrm{a}$ & $\begin{array}{l}\text { Clinical, EPT, } \\
\text { QST, NB }\end{array}$ & $24 / 24$ \\
\hline 38 & $\operatorname{AASN}(21)$ & $\begin{array}{c}\text { Mean } 29 \pm 14.9 \\
15 / 6\end{array}$ & $\leq 1$ month & Clinical, EPT, NB & $20 / 21$ \\
\hline 39 & PSN (21) & $\begin{array}{c}\text { Median } 65(24-83) \\
11 / 10\end{array}$ & $\leq 1$ month & $\begin{array}{c}\text { Clinical, NIS, EPT, } \\
\text { QST, NB }\end{array}$ & $18 / 21$ \\
\hline$(0$ & ANN (13) & $\begin{array}{c}\text { Mean } 37(16-54) \\
13 / 0\end{array}$ & $\begin{array}{c}\text { Acute: } \leq 4 \text { weeks } \\
\text { Subacute: } \leq 12 \text { weeks }\end{array}$ & Clinical, NRS, EPT, NB, SB & $13 / 13$ \\
\hline 41 & $\begin{array}{l}\text { Paraneoplastic ( } \mathrm{Hu} \\
\text { and some } \mathrm{CV} 2 \\
\text { positive) (12) }\end{array}$ & $\begin{array}{c}\text { Median } 64(42-80) \\
3 / 17\end{array}$ & $\begin{array}{l}\text { Acute: } \leq 1 \text { month } \\
\text { Subacute: } 1-6 \\
\text { months }\end{array}$ & Clinical, EPT & $9 / 12$ \\
\hline
\end{tabular}

${ }^{*}$ Data for patients with neuropathic pain only.

§Exposure to aerolised brain tissue during pig carcasses' processing in US abattoirs

AASN: Acute Autonomic and Sensory Neuropathy, ACIPN: Acute Chemotherapy Induced Peripheral Neuropathy, ANN: Acute Nutritional Neuropathy, BPI: Brief Pain Inventory, CSS: Churg Strauss Syndrome, DCRPN: Diabetic Cervical Radiculoplexus Neuropathy, DLRPN: Diabetic Lumbar Radiculoplexus Neuropathy, DN4: Douleur Neuropathique, EPT: Electrophysiology tests (i.e., nerve conduction studies with or without electromyography), GBS: Guillain-Barré syndrome, MFS: Miller-Fisher Syndrome, MPQ: McGill Pain Questionnaire, NB: Nerve biopsy, NDS: Neurological Disability Score, NIS: Neuropathy Impairment Score, NPSI: Neuropathic Pain Symptom Inventory, NRS: 11-point numeric rating scale for pain intensity or visual analog scale 0-10 cm, NSS: Neurological Symptom Score, NSVN: Non-Systemic Vasculitic Neuropathy, PSN: Postsurgical Neuropathy, QST: Quantitative Sensory Testing, SB: skin biopsy, TIND: Treatment-induced Neuropathy of Diabetes, n/a: not available

Table 2. Rare causes of acute neuropathy presenting with neuropathic pain.

\begin{tabular}{|l||}
\hline Vasculitic neuropathies \\
\hline Polyarteritis Nodosa (42) \\
\hline SLE (43,44) \\
\hline Wegener's granulomatosis (45) \\
\hline Sarcoidosis (46) \\
\hline Infectious neuropathies(e.g., herpetic, rickettsiosis, West Nile, HIV) (47-51) \\
\hline $\begin{array}{l}\text { Toxic neuropathies (e.g., antiretroviral drugs, metronidazole, fluoroquinolone, minocycline, rabbit antithymocyte globulin, heroin, fish } \\
\text { poisoning, thallium, organophosphate poisoning) (52-61) }\end{array}$ \\
\hline Primary neurolymphomatosis (in non-Hodgkin lymphoma and leukemia) (62-66) \\
\hline Rare paraneoplasticacute neurological syndromes (67,68) \\
\hline Critical illness polyneuropathy (69,70) \\
\hline Acute branchial neuritis (Parsonage-Turner Syndrome) (71-77) \\
\hline Erythromelalgia (78,79) \\
\hline Subacute peripheral and optic neuropathy syndrome (80,81) \\
\hline Hereditary motor and sensory neuropathy (MPZ mutation) (82) \\
\hline \hline
\end{tabular}


peripheral NP, radicular pain, meningism, headache, muscular pain secondary to bad posture, visceral pain, and arthralgias (13-24,83). Pain can be acute, subacute, or chronic and it may appear in all GBS variants (e.g., mild GBS, pure motor GBS, pure sensory GBS, etc), albeit patients with MFS tend to show significantly reduced incidence of acute neuropathic pain (84). Although NP in GBS is usually not among the first manifestations, in some cases it can precede or coincide with weakness. Interestingly, pain in GBS was more conspicuous in patients with nerve root enhancement in magnetic resonance imaging (MRI) compared to patients with no enhancement (22).

AASN is a rare entity causing monophasic variable autonomic and sensory disturbances with a peak severity during a short period of time, usually preceded by an infection (38). This is primarily an axonal neuropathy of unmyelinated and mainly small myelinated nerve fibers, explaining the lack of motor symptoms in these patients. Also, the wide distribution of sensory and autonomic symptoms and signs resemble that of a ganglionopathy affecting both sensory and autonomic ganglia. Further support of a ganglionopathy is rendered by the sparing of motor function despite the late appearance of symptoms and signs indicative of deep sensory impairment. Some authors consider this entity as a variant of GBS (pure sensory type) in the light of similarities concerning the rapid clinical progression, preceding infection, albuminocytologic dissociation, and response to intravenous immunoglobulin (38).

PSN is an acute inflammatory neuropathy occurring within one month after surgery that cannot be attributed to mechanical factors (e.g., compression neuropathy). It is a sensorimotor axonal neuropathy manifested as polyradiculopathy, plexopathy, polyneuropathy, or mononeuropathy. The clinical course is benign with symptoms abating with or without immunosuppressive therapy (39).

With respect to the pathogenesis, NP has been associated with damage of the small unmyelinated nerve fibers carrying thermal and nociceptive sensation as attested by low intraepidermal nerve fiber density (IENFD) in skin biopsies (20). Notably, NP in GBS can exist without clinical evidence of sensory symptoms or signs and sensory nerve abnormalities in nerve conduction studies (NCS), which makes it difficult to differentiate by other types of pain. In these occasions, NP has been attributed to nociceptive activation of the nervi nervorum of the motor nerves by inflammatory mediators, or spontaneous discharges of dying motor axons in axonal GBS (14). However, low IENFD has been linked to both increased NP incidence and severity, even in patients with pure motor GBS (20). Neck and/or back pain have been imputed to swollen nerve roots and muscle pains or changes in muscles of neurogenic origin (i.e., activation of the muscles' nociceptive receptors due to increased dying motor neurons discharges) (42). Finally, increased intracranial pressure has been observed in GBS patients causing headache and meningism (43).

\section{Diabetes Related Acute/Subacute Neuropathies}

TIND (also known as "insulin neuritis") is an acute painful neuropathy occurring within about 2 months after rapid correction of serum glucose or a decrease above $2 \%$ of glycosylated haemoglobin (HB1ac) per 3 months, with insulin or oral hypoglycemic agents after a long history of hyperglycemia (25-27). Pain initially affects distal limbs or even abdomen and rapidly generalizes to affect the whole body (25-27). Pain is accompanied by autonomic symptoms (e.g., syncope, orthostatic hypotension, early satiety, constipation, diarrhea, hypohidrosis, hyperhidrosis, etc.) suggesting a small fiber pathology (25-27). Interestingly, larger decrements of HB1ac have been associated with more widespread body surface area affected by pain and more severe autonomic dysfunction (25). It is usually a self-limited condition often taking many months before full improvement. NCS's reveal axonal mainly sensory, but also motor neuropathy (25-27). The pathogenesis of TIND remains elusive. Mechanisms such as endoneurial ischemia due to a "steal effect" by proliferating new vessels and arteriovenous shunting in the epineurium, microvascular changes due to recurrent hypoglycemia, apoptosis in the dorsal root ganglia due to glucose deprivation, and accelerated regeneration of small fibers producing ectopic discharges, have been postulated (25).

Diabetic cervical plexopathy and diabetic lumbosacral plexopathy usually occur independently and are unilateral; however, simultaneous presentation of 2 plexopathies has been reported. Both syndromes are mostly monophasic characterized by acute or subacute pain, weakness and weight loss, all leading to transient disability. Axonal ischemic injury due to microvasculitic changes is the main pathological finding in biopsies of the affected nerves (28). The role of the immune system in the pathogenesis of these disorders is still debatable.

\section{Cancer Related Acute/Subacute Neuropathies}

ACIPN presents immediately after administration of 
the chemotherapeutic drug (e.g., oxaliplatin, paclitaxel) and is characterized by NP starting mainly in the hands, feet, or face, with cold sensitivity and cold-induced pain (indicating mainly $A \delta$ fiber damage) being the most commonly reported symptom by over $80 \%$ of patients (29-31). The incidence of pain and its duration increase with larger cumulative doses of the chemotherapeutic drug (85). Other risk factors for ACIPN are genetic polymorphisms, pre-existing peripheral neuropathy, history of smoking, and decreased creatinine clearance (85). The pathogenesis of this dose-dependent neurotoxicity is not clear; however, ion conductance anomalies and apoptosis of cells in the dorsal root ganglia have been proposed (85).

Primary neurolymphomatosis, a rare manifestation of non-Hodgkin lymphoma and leukemia, is caused by infiltration of the peripheral nervous system by cancer cells (62-66). Positron emission tomography and nerve biopsy may assist the diagnosis.

Paraneoplastic neurologic syndromes (PNS) are a heterogeneous group of disorders caused by mechanisms other than metastases, metabolic and nutritional deficits, infections, coagulopathy, or side effects of cancer treatment. These syndromes may affect any part of the nervous system from cerebral cortex to neuromuscular junction and muscle. The immunologic response is directed against shared antigens that are ectopically expressed by the tumor, but otherwise exclusively expressed by the nervous system. Subacute sensory neuronopathy (or Denny-Brown syndrome) causing severe widespread pain belongs to the "classical syndromes" meaning that there is strong evidence in favor of concomitant or impending cancer (41). Hu and CV2 antibodies are well-characterized antibodies associated with subacute sensory neuronopathy (41). Pain is very prevalent in paraneoplastic sensory ganglionopathies as it can affect up to $60 \%$ of patients during the course of the PNS. Pain is among the first symptoms of the paraneoplastic neuropathy in more than $40 \%$ of the patients and it can be the sole first manifestation of the paraneoplastic neuropathy in $13 \%$ of the patients $(86,87)$.

\section{Vasculitic Neuropathies}

Vasculitic neuropathies manifest with pain of abrupt onset and weakness of the muscles innervated by the nerve which is affected. Electrophysiologically vasculitic neuropathy is characterized by an asymmetrical, nonlength dependent sensorimotor axonal degeneration, however with time, accumulation of many mononeuropathies might mimic a symmetrical polyneuropathy making diagnosis more challenging (32-35).

Systemic symptoms (e.g., fever, weight loss, increased inflammatory markers and organ-specific symptoms, or abnormal laboratory studies) may further assist diagnosis of the underlying cause. In the nonsystemic vasculitic neuropathies, the systemic manifestations are more negligible and only nerve and/or muscle biopsy showing necrotizing inflammation of the vasa nervorum can establish the diagnosis.

\section{Acute/subacute Neuropathies Due to Deficiencies}

ANN is an acute/subacute sensory or sensorimotor length-dependent axonal neuropathy preceded by weight loss, vomiting, and nutritional derangements due to alcohol abuse, bariatric surgery, or other dietary problems (40). Sensory small fiber involvement may account for NP in these cases. Distinction between ANN and GBS can be made on the basis of onset for many days or weeks, lack of preceding infection, absence of cranial nerve involvement and respiratory compromise, and negative anti-ganglioside antibodies. Thiamine deficiency may be the major culprit for this disorder.

Subacute peripheral and optic neuropathy syndrome occurs mainly in metabolic disorders (e.g., B12 or folic acid or copper or thiamine deficiency) and alcoholism. Genetic susceptibility to the syndrome involving mitochondrial DNA mutations is strongly suspected $(80,81)$. The syndrome is characterized by a predominantly sensory distal symmetric painful neuropathy affecting the lower limbs more than the upper limbs. In some cases, marked ataxia denote concomitant ganglionopathy. Visual symptoms may precede or follow the peripheral neuropathy in a period of one month after onset, which is pathognomonic for the syndrome $(80,81)$.

\section{Discussion}

This systematic review included a total of 70 publications in order to calculate the incidence of NP in acute and subacute peripheral neuropathies of various etiologies.

This systematic review has a number of limitations. First of all, we searched only MEDLINE, thus there is a chance that some studies have been missed. Furthermore, a major limitation for NP incidence estimation was that GBS accounted for the majority of patients with acute neuropathies. It is, thus, more likely that the final incidence of NP would be influenced mostly by this disease entity. However, given that GBS is the most 
frequent acute neuropathy, the estimated incidence gives the clinician a rough estimate of NP in acute neuropathies taking into account their frequency. Another important limitation was that very few studies targeted solely or primarily on NP, thus data on NP diagnosis and occurrence might be misleading. For the same reason, it is highly likely that we have missed observational studies reporting NP as part of the clinical characteristics of their clinical samples. Finally, there could always be a publication bias due to underreporting negative results and gray literature.

Our paper indicated the following key points:

1. The overall pooled incidence of NP in acute and subacute neuropathies is $48.7 \%$. The diseasespecific pooled incidence of NP showed that some acute/subacute neuropathies are almost always painful (such as the diabetes related) when others are affecting a smaller percentage of patients (such as in GBS). More observational studies reporting the incidence of NP in acute/subacute neuropathies of various etiologies are needed in order to have a clearer picture of the exact figures.

2. Adequate diagnosis of NP is lacking as not all studies reported how NP was defined or whether validated tools for the diagnosis of the neuropathic element of pain were used. Therefore, there is always a chance that any pain reported by some patients would be ascribed as NP by physicians, especially on the basis of an acute/subacute peripheral neuropathy diagnosis. Screening tools only offer guidance for further evaluation and they should not replace clinical judgment (5). On the other hand, clinical judgment of NP should adhere to a specified criterion-based context that would prevent arbitrary reporting.

3. The terms "acute" and "subacute" were used variably in the studies presented in this review.
"Acute" definitions ranged from 1 day to 8 weeks after symptom onset and "subacute" definitions ranged from 1 day to 3 months. In general, acute and subacute neuropathies characteristically cause symptoms that evolve quickly and start to abate (with or without therapy) within 4 to 8 weeks, respectively (2-5). However, some clinicians still use "acute" to describe a well-defined steep onset and/ or severe symptoms. In our view, acute, subacute and chronic NP should correspond to both clinical and pathological evidence. In any case, there is a need for clearly defining the timeframes during which pain will be considered as acute, subacute, or chronic. As such, the terms hyperacute, acute, subacute, and chronic for NP implicating small sensory fibers (mainly $C$ and $A \delta$ fibers), should be refrained for symptom onset within 24 hours (to address situations such as ACIPN and toxic neuropathies), 24 hours to one month (during which a growing number of axons is lost), 1-3 months (axon loss has been roughly maximized given that the first insult is absent and regeneration occurs), and over 3 months ( 3 months are considered the start of the normal healing period and skin reinnervation by surviving axons in sensory neuropathies, reaching its peak in 5-6 months), respectively $(2-5,88)$.

\section{Conflicts of Interest}

The authors declare that there is no conflict of interest regarding the publication of this article.

\section{Acknowledgments}

The authors contributed equally to the conception, acquisition of the studies, interpretation of the results, writing, drafting, revising, and final approval of this manuscript. This study received no funding (Level 0).

\section{References}

1. Smith $\mathrm{BH}$, Torrance N. Epidemiology of neuropathic pain and its impact on quality of life. Curr Pain Headache Rep 2012; 16:191-198.

2. Merskey H, Bogdukeds N. Classification of chronic pain: descriptions of chronic pain syndromes and definitions of pain terms. 2nd ed. WA: IASP Press, Seattle, 1994.
3. Treede RD, Jensen TS, Campbell JN, Cruccu G, Dostrovsky JO, Griffin JW, Hansson P, Hughes R, Nurmikko T, Serra J. Neuropathic pain: Redefinition and a grading system for clinical and research purposes. Neurology 2008; 70:1630-1635.

4. McArthur JC. Painful small fiber neuropathies. Continuum (Minneap Minn) 2012; 18:106-125.
5. Baron R, Binder A, Wasner G. Neuropathic pain: Diagnosis, pathophysiological mechanisms, and treatment. Lancet Neurol 2010; 9:807-819.

6. Melzack R. The McGill Pain Questionnaire: Major properties and scoring methods. Pain 1975; 1:277-299.

7. Melzack R. The short-form McGill Pain Questionnaire. Pain 1987; 30:191-197. 
8. Galer BS, Jensen MP. Development and preliminary validation of a pain measure specific to neuropathic pain: The Neuropathic Pain Scale. Neurology 1997; 48:332-338.

9. Bouhassira D, Attal N, Fermanian J, Alchaar H, Gautron M, Masquelier E, Rostaing S, Lanteri-Minet M, Collin E, Grisart J, Boureau F. Development and validation of the Neuropathic Pain Symptom Inventory. Pain 2004; 108:248-257.

10. Sykioti $P$, Zis $P$, Vadalouca A, Siafaka I, Argyra E, Bouhassira D, Stavropoulou E, Karandreas N. Validation of the Greek version of the DN4 Diagnostic Questionnaire for Neuropathic Pain. Pain Pract 2015; 15:627-632.

11. Zis P, Sarrigiannis PG, Rao DG, Hewamadduma C, Hadjivassiliou M. Chronic idiopathic axonal polyneuropathy: A systematic review. J Neurol 2016; 263:1903-1910.

12. Crone C, Krarup C. Diagnosis of acute neuropathies. J Neurol 2007; 254:1151-1169.

13. Wu X, Shen D, Li T, Zhang B, Li C, Mao M, Zhao J, Liu K, Zhang HL. Distinct clinical characteristics of pediatric Guillain-Barré syndrome: A comparative study between children and adults in Northeast China. Plos One 2016; 11:e0151611.

14. Ruts L, Rico R, van Koningsveld R, Botero JD, Meulstee J, Gerstenbluth I, Merkies IS, van Doorn PA. Pain accompanies pure motor Guillain-Barré syndrome. J Peripher Nerv Syst 2008; 13:305-306.

15. Ruts $L$, van Koningsveld $R$, Jacobs $B C$, van Doorn PA. Determination of pain and response to methylprednisolone in Guillain-Barré syndrome. J Neurol 2007; 254: 1318-1322.

16. Ruts L, Drenthen J, Jongen JL, Hop WC, Visser GH, Jacobs BC, van Doorn PA; Dutch GBS Study Group. Pain in Guillain-Barré syndrome: A longterm follow-up study. Neurology 2010; 75:1439-1447.

17. Sharshar T, Polito A, Porcher R, Merhbene $T$, Blanc $M$, Antona $M$, Durand MC, Friedman D, Orlikowski D, Annane $\mathrm{D}$, Marcadet $\mathrm{MH}$. Relevance of anxiety in clinical practice of Guillain-Barré syndrome: A cohort study. BMJ Open, 2012; 2:e000893.

18. Moulin DE, Hagen N, Feasby TE, Amireh R, Hahn A. Pain in Guillain-Barré syndrome. Neurology 1997; 48:328-331.
19. Forsberg A, Press R, Einarsson U, de Pedro-Cuesta J, Widén Holmqvist L; Swedish Epidemiological Study Group. Impairment in Guillain-Barré syndrome during the first 2 years after onset: A prospective study. J Neurol Sci 2004; 227:131-138.

20. Ruts L, van Doorn PA, Lombardi R, Haasdijk ED, Penza P, Tulen JH, Hempel RJ, van den Meiracker AH, Lauria G. Unmyelinated and myelinated skin nerve damage in Guillain-Barré syndrome: A correlation with pain and recovery. Pain 2012; 153:399-409.

21. Martinez $V$, Fletcher D, Martin F, Orlikowski D, Sharshar T, Chauvin M, Bouhassira D, Attal N. Small fibre impairment predicts neuropathic pain in Guillain-Barré syndrome. Pain 2010; 151:53-60.

22. Gorson KC, Ropper AH, Muriello MA, Blair R. Prospective evaluation of MRI lumbosacral nerve root enhancement in acute Guillain-Barré syndrome. Neurology 1996; 47:813-817.

23. Green DM, Ropper AH. Mild GuillainBarré syndrome. Arch Neurol 2001; 58:1098-1101.

24. Koga M, Yuki N, Hirata K. Pain in Miller Fisher syndrome. J Neurol 2000; 247:720-721.

25. Gibbons $\mathrm{CH}$, Freeman R. Treatment-induced neuropathy of diabetes: An acute, iatrogenic complication of diabetes. Brain 2015; 138:43-52.

26. Knopp M, Srikantha M, Rajabally YA. Insulin neuritis and diabetic cachectic neuropathy: A review. Curr Diabetes Rev 2013; 9:267-274.

27. Gibbons $\mathrm{CH}$, Freeman R. Treatment induced diabetic neuropathy: A reversible painful autonomic neuropathy. Ann Neurol 2010; 67:534-541.

28. Massie R, Mauermann ML, Staff NP, Amrami KK, Mandrekar JN, Dyck PJ, Klein CJ. Diabetic cervical radiculoplexus neuropathy: A distinct syndrome expanding the spectrum of diabetic radiculoplexus neuropathies. Brain 2012; 135:3074-3088.

29. Leonard GD, Wright MA, Quinn MG, Fioravanti S, Harold N, Schuler B, Thomas RR, Grem JL. Survey of oxaliplatin-associated neurotoxicity using an interview-based questionnaire in patients with metastatic colorectal cancer. BMC Cancer 2005; 5:116.

30. Reeves BN, Dakhil SR, Sloan JA, Wolf
SL, Burger KN, Kamal A, Le-Lindqwister NA, Soori GS, Jaslowski AJ, Kelaghan J, Novotny PJ, Lachance DH, Loprinzi CL. Further data supporting that paclitaxelassociated acute pain syndrome is associated with development of peripheral neuropathy: North Central Cancer Treatment Group trial No8C1. Cancer 2012; 118:5171-5178.

31. Binder A, Stengel M, Maag R, Wasner G, Schoch R, Moosig F, Schommer B, Baron R. Pain in oxaliplatin-induced neuropathy-sensitisation in the peripheral and central nociceptive system. Eur J Cancer 2007; 43:2658-2663.

32. Mori K, lijima M, Koike $H$, Hattori $N$, Tanaka F, Watanabe H, Katsuno M, Fujita A, Aiba I, Ogata A, Saito T, Asakura K, Yoshida M, Hirayama M, Sobue G. The wide spectrum of clinical manifestations in Sjögren's syndrome-associated neuropathy. Brain 2005; 128:2518-2534.

33. Üçeyler N, Geng A, Reiners K, Toyka KV, Sommer C. Non-systemic vasculitic neuropathy: Single center follow-up of 60 patients. J Neurol 2015; 262:2092-2100.

34. Hattori $N$, Ichimura $M$, Nagamatsu $M$, Li M, Yamamoto K, Kumazawa K, Mitsuma T, Sobue G. Clinicopathological features of Churg-Strauss syndromeassociated neuropathy. Brain 1999; 122:427-439.

35. Santos-Pinheiro F, Li Y. Eosinophilic granuloamtosis with polyangiitis (Churg-Strauss syndrome) presenting with polyneuropathy: A case series.] Clin Neuromuscul Dis 2015; 16:125-130.

36. Logina I, Krumina A, Karelis G, Elsone L, Viksna L, Rozentale B, Donaghy M. Clinical features of double infection with tick-borne encephalitis and Lyme borreliosis transmitted by tick bite. J Neurol Neurosurg Psychiatry 2006; 77:1350-1353.

37. Lachance DH, Lennon VA, Pittock SJ, Tracy JA, Krecke KN, Amrami KK, Poeschla EM, Orenstein R, Scheithauer BW, Sejvar JJ, Holzbauer S, Devries AS, Dyck PJ. An outbreak of neurological autoimmunity with polyradiculoneuropathy in workers exposed to aerosolised porcine neural tissue: A descriptive study. Lancet Neurol 2010; 9:55-60.

38. Koike $\mathrm{H}$, Atsuta $\mathrm{N}$, Adachi $\mathrm{H}$, lijima M, Katsuno M, Yasuda T, Fukada Y, Yasui K, Nakashima K, Horiuchi M, Shiomi K, Fukui K, Takashima S, Morita Y, Kuniyoshi K, Hasegawa Y, Toribe Y, Kajiura M, Takeshita S, Mukai E, Sobue G. Clinico- 
pathological features of acute autonomic and sensoryneuropathy. Brain 2010; 133:2881-2896.

39. Staff NP, Engelstad J, Klein CJ, Amrami KK, Spinner RJ, Dyck PJ, Warner MA Warner ME. Post-surgical inflammatory neuropathy. Brain 2010; 133:2866-2880.

40. Hamel J, Logigian EL. Acute nutritional axonal neuropathy. Muscle Nerve 2018; 57:33-39.

41. Camdessanché JP, Antoine JC, Honnorat J, Vial C, Petiot P, Convers P, Michel D. Paraneoplastic peripheral neuropathy associated with anti-Hu antibodies. A clinical and electrophysiological study of 20 patients. Brain 2002; 125:166-175.

42. Lozeron P, Lacroix C, Michon M, Theau$\operatorname{din}$ M, Petit Lacour MC, Denier C, Adams $D$. Vasculitis neuropathy mimicking lower limb monoradiculopathy: A study and follow-up of 8 cases. Intern Emerg Med 2013; 8:601-609.

43. Ilniczky S, Kamondi A, Arányi Z, Várallyay G, Gaal B, Szirmai I, Nagy G. Simultanous central and peripheral nervous system involvement in systemic lupus erythematosus. Ideggyogy Sz 2007; 60:398-402.

44. Li X, Wang Y. Systemic lupus erythematosus with acute inflammatory demyelinating polyneuropathy: A case report and review of the literature. J Clin Med Res 2016; 8:555-559.

45. Gil E, Lutalo P, D'Cruz D. Systemic vasculitis: A dual diagnosis? BM] Case Rep 2011; 2011: bcr1020114968.

46. Miura S, Kusumoto M, Noda K, Azuma K, Toda R, Honda S, Ayabe M, Aizawa H, Taniwaki T. Bell-shaped sensory impairments of all modalities in a neurosarcoidosis patient. Clin Neurol Neurosurg 2007; 109:794-798.

47. Elamin M, Monaghan T, Mullins G, Ali E, Corbett-Feeney G, O'Connell S, Counihan TJ. The clinical spectrum of Lyme neuroborreliosis. Ir Med J 2010; 103:46-49.

48. Jensenius $M$, Fournier PE, Fladby $T$, Hellum KB, Hagen T, Priø T, Christiansen MS, Vene S, Raoult D, Myrvang B. Subacute neuropathy in patients with African tick bite fever. Scand J Infect Dis 2006; 38:114-118.

49. Vucic S, Palmer W, Cros D. Radiculoplexopathy with conduction block caused by acute Epstein-Barr virus infection. Neurology 2005; 64:530-532.

50. Jeha LE, Sila CA, Lederman RJ, Prayson
RA, Isada CM, Gordon SM. West Nile virus infection: a new acute paralytic illness. Neurology 2003; 61:55-59.

51. Bradley WG, Verma A. Painful vasculitic neuropathy in HIV-1 infection: relief of pain with prednisone therapy. Neurology 1996; 47:1446-1451.

52. Lorber M. A case of possible darunavir/ ritonavir-induced peripheral neuropathy: Case description and review of the literature. J Int Assoc Provid AIDS Care 2013; 12:162-165.

53. Simioni V, Capone JG, Sette E, Sensi M, Tola MR, Granieri E, Tugnoli V. Acute painful neuropathy in a heroin body packer. Pain Med 2014; 15:1236-1237.

54. Wu ML, Yang CC, Deng JF, Wang KY. Hyperkalemia, hyperphosphatemia, acute kidney injury, and fatal dysrhythmias after consumption of palytoxincontaminated goldspotherring. Ann Emerg Med 2014; 64:633-636.

55. Centers for Disease Control and Prevention (CDC). Thallium poisoning from eating contanimated cake-Iraq, 2008. MMWR Morb Mortal Wkly Rep 2008; 57:1015-1018.

56. Sarma GR, Kamath VR. Acute painful peripheral neuropathy due to metronidazole. Neurol India 2005; 53:372-373.

57. Dukewich M, Danesh A, Onyima C, Gupta A. Intractable acute pain related to fluoroquinolone-induced peripheral neuropathy. J Pain Palliat Care Pharmacother 2017; 31:144-147.

58. Cartwright MS, Moore PS, Donofrio PD, Iskandar SS, Stratta RJ. Acute sensory neuropathy associated with rabbit antithymocyte globulin. Am J Transplant 2007; 7:484-486.

59. Kuo HC, Huang CC, Tsai YT, Chu CC, Hsieh ST, Chu NS. Acute painful neuropathy in thallium poisoning. Neurology 2005; 65:302-304.

6o. Aygun D, Onar MK, Altintop BL. The clinical and electrophysiological features of a delayed polyneuropathy developing subsequently after acute organophosphate poisoning and it's correlation with the serum acetylcholinesterase. Electromyogr Clin Electrophysiol 2003; 43:421-427.

61. Baratta JM, Dyck PJ, Brand P, Thaisetthawatkul P, Engelstad JK, Goodman B, Karam C. Vasculitic neuropathy following exposure to minocycline. Neurol Neuroimmunol Neuroinflamm 2015; 3:e180.

62. Brandstadter R, Brody J, Morgello S,
Motiwala R, Shin S, Lublin F, Zhou L. Primary neurolymphomatosis presenting with polyradiculoneuropathy affecting one lower limb. J Clin Neuromuscul Dis 2015; 17:6-12.

63. Platten M, Opitz CA, Kohlhof P, Hegenbart U, Ho AD, Wick W. Painful neuropathy due to intraneural leukemic spread in a patient with acute myeloid leukemia. Neurology 2007; 69:707.

64. Groth CL, Nevel KS, Gwathmey KG, Bafakih F, Jones DE. Splenic marginal zone lymphoma: An indolent malignancy leading to the development of neurolymphomatosis. Muscle Nerve 2017; 55:440-444.

65. Lahoria R, Dyck PJ, Macon WR, Crum BA, Spinner RJ, Amrami KK, Zeldenrust SR, Tracy JA. Neurolymphomatosis: A report of 2 cases representing opposite ends of the clinical spectrum. Muscle Nerve 2015; 52:449-454.

66. Reddy CG, Mauermann ML, Solomon BM, Ringler MD, Jerath NU, Begna KH, Amrami KK, Spinner RJ. Neuroleukemiosis: An unusual cause of peipheral neuropathy. Leuk Lymphoma 2012; 53:2405-2411.

67. Jarius S, Ringelstein M, Haas J, Serysheva II, Komorowski L, Fechner K, Wandinger $\mathrm{KP}$, Albrecht $\mathrm{P}$, Hefter $\mathrm{H}$, Moser A, Neuen-Jacob E, Hartung HP, Wildemann B, Aktas O. Inositol 1,4,5-triphosphate receptor type 1 autoantibodies in paraneoplastic and non-paraneoplastic peripheral neuropathy. J Neuroinflammation 2016; 13:278.

68. Kannan MA, Challa S, Kandadai RM, Uppin MS, Jabeen SA, Borgohain R. Series of paraneoplasticvasculitic neuropathy: A rare, potentially treatable neuropathy. Neurol India 2015; 63:30-34.

69. Latronico N, Filosto M, Fagoni N, Gheza L, Guarneri B, Todeschini A, Lombardi R, Padovani A, Lauria G. Small nerve fiber pathology in critical illness. Plos One 2013; 8:e75696.

70. Skorna M, Kopacik R, Vlckova E, Adamova $B$, Kostalova M, Bednarik J. Smallnerve-fiber pathology in critical illness documented by serial skin biopsies. Muscle Nerve 2015; 52:28-33.

71. Kim KK. Acute brachial neuropathy-electrophysiological study and clinical profile. J Korean Med Sci 1996; 11:158-164.

72. Shaikh MF, Baqai TJ, Tahir H. Acute brachial neuritis following influenza vaccination. BM] Case Rep, 2012; 2012: bcr2012007673. 
73. Squintani G, Mezzina C, Lettieri C, Critelli A, Eleopra R. Unusual Parsonage-Turner syndrome with relapses and bilateral simultaneous anterior interosseous neuropathy. Neurol Sci 2009; 30:513-516.

74. Ayoub T, Raman V, Chowdhur M. Brachial neuritis caused by varicella-zoster diagnosed by changes in brachial plexus on MRI.J Neurol 2010; 257:1-4.

75. Avila JD, Lacomis D, Lam EM. Neuralgic amyotrophy associated with Hepatitis E virus infection: First case in the United States. J Clin Neuromuscul Dis 2016; 18:96-100.

76. Moriguchi K, Miyamoto K, Takada K, Kusunoki S. Four cases of anti-ganglioside antibody positive neuralgic amyotrophy with good response to intravenous immunoglobulin infusion therapy. J Neuroimmunol 2011; 238:107-109.

77. Fabian VA, Wood B, Crowley P, Kakulas BA. Herpes zoster brachial plexus neuritis. Clin Neuropathol 1997; 16:61-64.

78. Paticoff J, Valovska A, Nedeljkovic
SS, Oaklander AL. Defining a treatable cause of erythromelalgia: Acute adolescent autoimmune small-fiber axonopathy. Anesth Analg 2007; 104:438-441.

79. Dabby R, Gilad R, Sadeh M, Lampl Y, Watemberg N. Acute steroid responsive small-fiber sensory neuropathy: A new entity? J Peripher Nerv Syst 2006; 11:47-52.

8o. Allen D, Riordan-Eva P, Paterson RW, Hadden RD. Subacute peripheral and toxic neuropathy syndrome with no evidence of a toxic or nutritional cause. Clin Neurol Neurosurg 2013; 115:1389-1393.

81. Spinazzi M, Angelini C, Patrini C. Subacute sensory ataxia and optic neuropathy with thiamine deficiency. Nat Rev Neurol 2010; 6:288-293.

82. Burns TM, Phillips LH 2nd, Dimberg EL, Vaught BK, Klein CJ. Novel myelin protein zero mutation (Arg36Trp) in a patient with acute onset painfu neuropathy. Neuromuscul Disord 2006; 16:308-310.

83. Pentland B, Donald SM. Pain in the
Guillain-Barré syndrome: A clinical review. Pain 1994; 59:159-164.

84. Farmakidis C, Inan S, Milstein M, Herskovitz S. Headache and pain in Guillain-Barré syndrome. Curr Pain Headache Rep 2015; 19:40.

85. Seretny M, Currie GL, Sena ES, Ramnarine S, Grant R, MacLeod MR, Colvin LA, Fallon M. Incidence, prevalence, and predictors of chemotherapy-induced peripheral neuropathy: A systematic review and meta-analysis. Pain 2014; 155:2461-2470.

86. Zis P, Paladini A, Piroli A, McHugh PC, Varrassi G, Hadjivassiliou M. Pain as a first manifestation of paraneoplastic neuropathies: A systematic review and meta-analysis. Pain Ther 2017; 6:143-151.

87. Zis P, Varrassi G. Painful peripheral neuropathy and cancer. Pain Ther 2017; [Epub ahead of print].

88. Lisney SJ. Regeneration of unmyelinated axons after injury of mammalian peripheral nerve. QJ Exp Physiol 1989; 74:757-784 